\title{
Waardenburg syndrome type 3
}

INSERM

\section{Source}

INSERM. (1999). Orphanet: an online rare disease and orphan drug data base.

Waardenburg syndrome type 3. ORPHA:896

Waardenburg syndrome type 3 (WS3) is a very rare subtype of Waardenburg syndrome (WS; see this term) that is characterized by limb anomalies in association with congenital hearing loss, minor defects in structures arising from neural crest, resulting in pigmentation anomalies of eyes, hair, and skin. 